\title{
INFLUENCE OF PELLETED BROWSE-BASED SUPPLEMENTS FED WITH A BASAL DIET OF Andropogon gayanus HAY ON INTAKE, DIGESTIBILITY, GROWTH AND HAEMATO-BIOCHEMICAL INDICES IN WEST AFRICAN DWARF GOAT
}

\author{
Leonard ADJORLOLO ${ }^{1}$, Emmanuel AMPONG² ${ }^{2}$, Akwasi MENSAH-BONSU³ and Frederick OBESE ${ }^{2 \star m}$ \\ ${ }_{1}^{1}$ Livestock and Poultry Research Centre, School of Agriculture, University of Ghana, Legon, Ghana \\ 2Department of Animal Science, School of Agriculture, University of Ghana, Legon, Ghana \\ ${ }^{3}$ Department of Agricultural Economics and Agribusiness, School of Agriculture, University of Ghana, Legon, Ghana \\ Email: fobese@ug.edu.gh; (DorciD: 0000-0001-6747-4786 \\ supporting Information
}

\begin{abstract}
This study evaluated the nutritional value of pelleted supplements based on four major feed resources fed to small ruminants by smallholder farmers in the Accra Plains. Leaves of Samanea saman, Acacia auriculiformis and Ficus exasperata, and cassava peels were dried, milled, mixed with other ingredients and pelleted to form Samanea saman (SS-S), Acacia auriculiformis (AA-S), Ficus exasperata (FE-S) and cassava peel (CP-S) based supplements. The supplements were fed to twenty West African Dwarf goats on a basal diet of Andropogon gayanus (Gamba grass) hay in a completely randomised design experiment. Voluntary intake of dry matter did not differ $(P>0.05)$ by the type of supplement. However, crude protein intake was higher $(P<0.05)$ in goats fed FE-S than those fed CP-S. Acid detergent fibre intake was higher $(P<0.05)$ for SS-S, AA-S and FE-S than CP-S. Digestibility of dry matter, organic matter, crude protein, acid detergent fibre and neutral detergent fibre were lowest $(P<0.05)$ for goats on CP-S. Average daily weight gain and Feed conversion ratio were not affected $(P>0.05)$ by dietary treatments. Also, dietary treatment did not affect $(P>0.05)$ the concentrations haematological and blood biochemical constituents determined except urea which was higher $(P<0.05)$ in goats fed SS-S than the other treatments. In conclusion, the above results suggest that browse-based and cassava peel-based supplements could be fed to confined goats on roughage diets especially in the dry season without any deleterious effects on intake, growth and physiology of goats.
\end{abstract}

Keywords: Accra plains, Performance, Shrub Leaves, Smallholder Farmers, Supplementation

Abbreviations: AA-S: Acacia auriculiformis-based supplement; ADMD: Apparent digestibility of dry matter; ANOVA: Analysis of variance; AOAC: Association of Official Analytical chemists; CP-s: cassava peel-based supplement; FE-B: Ficus exasperatabased supplement; LIPREC: Livestock and Poultry Research Centre; MCV: mean corpuscular volume; MCH: mean corpuscular haemoglobin; MCHC: mean corpuscular haemoglobin concentration; PCV: packed cell volume; RBC: red blood cell; SEM: standard error of mean; SS-S: Samanea saman-based supplement; T. Cholesterol: total cholesterol; WBC: white blood cell

\section{INTRODUCTION}

Small ruminant production is a major livelihood diversification strategy among smallholder farmers in Ghana. Often, animals are grazed extensively on natural pasture with little or no feed supplementation coupled with minimal health care (Baiden and Obese, 2010). However, restrictions in animal movement, especially during the cropping seasons, are now compelling many small ruminant keepers to fully or partially confine their animals. Feeding of confined small ruminants is often inadequate and such animals perform less than their free-roaming counterparts (Baah et al., 2012). The challenges associated with confinement in the cropping season, coupled with the scarcity of quality feed during the dry season severely constrain small ruminant production in Ghana (Adjorlolo et al., 2016) affecting income generation. Slow growth rate, unstable weight gains, lowered resistance to diseases and reproductive problems of small ruminants have been reported in these instances (Annor et al., 2007, Konlan, 2010). The provision of appropriate supplementary feed which can supply substantial amounts of dietary energy, protein and minerals would be an important step in enhancing the productivity of ruminants in Ghana.

Recently, Adjorlolo et al. (2020) fed pelleted Samanea saman, Acacia auriculiformis and Ficus exasperata leaf mealbased diets and cassava peel meal- based diet as supplements to West African Dwarf sheep fed on a basal diet of Andropogon gayanus (Gamba grass) hay and concluded that they were acceptable to sheep and could help improve performance on low quality forages.

Currently, there is lack of information on the utilization of browse-based pelleted feed supplements on the growth and physiology of the West African Dwarf goat the most popular goat breed in Ghana. This study therefore evaluated the effects of pelleted Samanea saman (SS-S), Acacia auriculiformis (AA-S), Ficus exasperata (FE-S) and cassava peel-based 
(CP-S) supplements on feed intake, growth rate and blood profiles of West African goats fed basal diet of Andropogon gayanus (Gamba) grass hay.

\section{MATERIALS AND METHODS}

\section{Study area}

The study was conducted at the Livestock and Poultry Research Centre (LIPREC) of the University of Ghana $\left(05^{\circ} 68^{\prime}\right.$ $\mathrm{N}, 00^{\circ} 10^{\prime} \mathrm{W}$ ) in the Coastal Savannah belt of Ghana, West Africa. Annual rainfall averages $881 \mathrm{~mm}$ per annum but with a high degree of variability. The rainy season was from April to June, the minor season was from September to October, and the dry season from November to March (Adjorlolo et al., 2014).

\section{Experimental animals and their management}

West African Dwarf goats were housed in individual pens with concrete floors. The housing unit had roofs made of corrugated iron sheets. The pens were $3 \mathrm{~m} \times 1.5 \mathrm{~m}$ in dimension. Each pen had one wooden feeding trough for the basal diet and two plastic troughs, one for the supplement and the other for water, similar to the study by Adjorlolo et al. (2020). The animals were treated against external parasites with pour-on acaricide and dewormed with Albendazole (10\%), a broad-spectrum anthelminthic. All the procedures in this study were approved by the Noguchi Memorial Institute for Medical Research Institutional Animal Care and Use Committee (NIACUC), University of Ghana (NIACUC Protocol No: 2017-03-2R).

\section{Preparation of experimental diets}

Leaves of three browse plants, namely, Samanea saman, Acacia auriculiformis and Ficus exasperata were harvested from trees and shrubs within the study area and shade-dried. Cassava peels were bought from gari producers and sundried. The dried leaves and cassava peels were ground with a hammer mill (1-mm screen) into meals and each mixed with other ingredients (Table 1) and pelleted. Andropogon gayanus (Gamba grass) was harvested at the flowering and seeding stage, sun-dried and tied in bundles for storage.

\section{Table 1 - Ingredient composition of supplements used in the study}

\begin{tabular}{|c|c|c|c|c|}
\hline \multirow{2}{*}{ Ingredients: (g/kg) } & \multicolumn{4}{|c|}{ Supplements } \\
\hline & SS-S & AA-S & FE-S & CP-S \\
\hline Maize & 159 & 124 & 165 & 0 \\
\hline Wheat bran & 120 & 135 & 108 & 650 \\
\hline Mineral salt & 5 & 5 & 5 & 5 \\
\hline Dicalcium phosphate & 5 & 5 & 5 & 5 \\
\hline Sulphate of ammonia & 5 & 5 & 5 & 5 \\
\hline Urea & 6 & 26 & 12 & 15 \\
\hline Cassava peels & 0 & 0 & 0 & 32 \\
\hline Samanea saman & 700 & 0 & 0 & 0 \\
\hline Acacia auriculiformis & 0 & 700 & 0 & 0 \\
\hline Ficus exasperata & 0 & 0 & 700 & 0 \\
\hline Total (Kg) & 1000 & 1000 & 1000 & 1000 \\
\hline Crude protein (Calculated) & 160.6 & 160.1 & 160.7 & 160.7 \\
\hline
\end{tabular}

The pelleted supplements were formulated to be isonitrogenous using literature values of nitrogen concentrations in the browses and cassava peels. The dietary treatments were as follows:

SS-S = Gamba grass hay + Samanea saman leaf meal-based supplement

AA-S = Gamba grass hay + Acacia auriculiformis leaf meal-based supplement

FE-S = Gamba grass hay + Ficus exasperata leaf meal-based supplement

CP-S = Gamba grass hay + Cassava peel meal-based supplement

\section{Voluntary feed intake and growth study}

The voluntary feed intake and growth studies were carried out using twenty young West African Dwarf goats with an initial average live weight of $10.7 \pm 2.3 \mathrm{~kg}$. They were allocated randomly to four experimental diets with each treatment having five replicates (five goats per treatment) in a completely randomized design. Animals in each treatment group were offered Gamba grass hay as basal diet and either of the three browses or cassava peel- based supplements. Supplements were offered at about 08:00 hours each day. Supplement allowance was about one percent of each animal's body weight (about $25 \%$ of voluntary intake). After each goat had consumed all the supplement provided, the basal diet was offered ad libitum. Animals were allowed 14 days to adjust to the diet after which daily feed intake and fortnightly body weights were taken for eleven weeks (77 days). Feed intake was determined daily as the difference between weight of feed offered and refusals. 


\section{Digestibility study}

For the digestibility studies, faecal collection bags were used to collect faecal samples from goats on the feeding trial. Faecal samples were taken from two goats per treatment for six days during the final week of the feeding trial. The faecal samples were stored in a refrigerator after collection. They were bulked for each goat and oven-dried at $55^{\circ} \mathrm{C}$ to a constant weight for dry matter (DM) determination. The dried faeces were ground through a $1.0 \mathrm{~mm}$ sieve using a laboratory mill and bagged pending further analysis. Apparent digestibility of dry matter (ADMD\%), was calculated as:

$$
\text { ADMD } \left.(\%)=\left(\frac{D M \text { intake }- \text { Faecal DM }}{D M \text { intake }}\right) \times 100\right)
$$

Similar calculations were followed to determine apparent digestibility of organic matter, crude protein, neutral detergent fibre, acid detergent fibre.

\section{Chemical analysis of feed and faeces}

Feed and faecal samples were analysed for dry matter, organic matter, crude protein and total ash according to the methods of AOAC (2004). Neutral detergent fibre (NDF), acid detergent fibre (ADF) and lignin were determined according to the method of Van Soest et al. (1991).

\section{Blood sampling}

Blood samples were collected every two weeks (week 1, 3,5, 7 and 9) from the jugular vein of each sheep using a vacutainer needle. Sampling was done in the morning, between 07:30 and 08:00 hours. A total of $10 \mathrm{ml}$ of blood sample was collected and $4 \mathrm{ml}$ transferred into a glass vacutainer tube containing the anticoagulant tripotassium ethylene diamine tetra acetic acid (K3.EDTA). The tubes were placed on ice and transported immediately to the Laboratory for haematological analysis. The remaining $6 \mathrm{ml}$ was transferred into glass vacutainer tubes containing clot (Gel) activator. This was placed on ice pack and also transported to the Laboratory where it was centrifuged at $3000 \mathrm{rpm}$ for 10 minutes at $4^{\circ} \mathrm{C}$. The sera obtained were gently harvested into Eppendorf tubes and stored at $-20^{\circ} \mathrm{C}$ until the analyzed for biochemical parameters.

\section{Haematological analysis}

The haemoglobin concentration was determined by the cyanmethaemoglobin method (Gillet et al., 2009), while PCV was estimated by the microhaematocrit method (Samour, 2006). The RBC and WBC counts were determined using the haemocytometer. Total RBC count was determined using the formula given by Samour (2006):

$\operatorname{RBC}\left(10^{12} / \mathrm{L}\right)=\frac{\mathrm{N}}{100}$, Where: $\mathrm{L}=$ Litre $; \mathrm{N}=$ Number of cells counted in 160 small squares.

Total WBC counts was estimated using the formula given by Campbell (1995): WBC $\left(10^{9} / \mathrm{L}\right)=\frac{\mathrm{N} \times 10 \times 200}{9}$, where:

$\mathrm{L}=$ litre; $\mathrm{N}=$ number of cells counted in nine small squares.

The RBC indices were computed using the formulas provided by Reece and Swenson (2004) below:

$$
\begin{aligned}
& \operatorname{MCV}(\mathrm{fL})=\left(\frac{P V C}{R B C}\right) \times 10 \\
& \operatorname{MCH}(\mathrm{pg})=\left(\frac{H b}{R B C}\right) \times 10 \\
& \operatorname{MCHC}(\mathrm{g} / \mathrm{dL})=\left(\frac{H b}{P C V}\right) \times 100
\end{aligned}
$$

In determining the differential WBC counts, thin smears of blood were made from blood samples obtained from venipuncture, on well ethanol-cleaned, grease-free microscope slides. They were air-dried, fixed in absolute methanol and stained with Giemsa stain. Stained slides were studied under oil immersion objective at $1000 \mathrm{X}$ magnification. Percentages of neutrophils, lymphocytes, monocytes, eosinophils and basophils were all determined based on observation of 200 WBC per film.

\section{Blood biochemical analysis}

The concentrations of glucose, total proteins, albumin, total cholesterol, urea, sodium and potassium were determined in the serum at weeks 1, 3, 5, 7 and 9 using the Mindray BA -88A Semi-Auto Chemistry Analyzer (Nanshan, China). Globulin concentration was computed as the difference between total protein and albumin concentrations.

\section{Statistical analyses}

Data from the feed intake, growth and digestibility studies were subjected to Analysis of variance procedure (ANOVA) of GenStat Release 12th Edition (VSN International, 2009), whilst that of the blood parameters was analyzed using repeated measures analysis of variance procedure of GenStat (VSN International, 2009). The Least significant difference procedure of GenStat was used to separate the means at $5 \%$ level of significance.

\section{RESULTS}

\section{Chemical composition of feed ingredients and supplements}

The chemical composition of the basal diet (Gamba grass hay), the three browses (Samanea, Acacia and Ficus) and cassava peels are presented in Table 2. The basal diet, the leaf meals of the three browses and cassava peels had comparable dry matter contents (88.3 to $91.4 \%)$ and organic matter (81.1 to $85.3 \%$ ) contents. Apart from cassava peels 
all the leaf meals of the three browses had higher crude protein than Gamba grass hay. Also, all the leaf meals of the browses and cassava peel-meal had lower neutral detergent fibre and lignin contents than Gamba grass. The chemical composition of the experimental supplements are shown in Table 3. AA-S had the highest crude protein content (22.3\%) while CP-S had the least (15.9\%).

\section{Influence of supplements on voluntary intakes in West African Dwarf goat}

Intakes of crude protein and acid detergent fibre were influenced by the type of supplement offered (Table 4). Sheep fed FE-S had higher $(P<0.05)$ crude protein intake than those fed CP-S. Acid detergent fibre intake was higher $(P<0.05)$ for SS-S, AA-S and FE-S than CP-S. The dry matter, organic matter, neutral detergent fibre and lignin intakes were however similar across dietary treatments.

\section{Digestibility of nutrients by West African Dwarf goat}

Digestibility of dry matter, organic matter, crude protein and detergent fibre were all influenced by the type of supplement fed (Table 5). Dry matter digestibility was similar for SS-S, AA-S and FE-S but higher $(P<0.05)$ than CP-B. Crude protein and neutral detergent fibre digestibilities also followed a similar tend to that of dry matter digestibility. Organic matter digestibility was higher $(P<0.05)$ for sheep fed SS-S and FE-S than those fed CP-S. Also, the acid detergent fibre digestibility in goats fed SS-S or AA-S were higher $(P<0.05)$ than those fed CP-B.

\section{Daily weight gain and feed conversion ratio}

Average daily weight gain and feed conversion ratios did not differ $(P>0.05)$ with the type of supplement (Table 6). None of the supplements led to weight loss in the goats.

\section{Table 2 - Chemical composition of leaf meals of browses, cassava peel meal and Andropogon gayanus hay}

\begin{tabular}{|c|c|c|c|c|c|}
\hline Fraction (\%) & Grass hay & Samanea & Acacia & Ficus & $\begin{array}{c}\text { Cassava } \\
\text { Peels }\end{array}$ \\
\hline Dry matter & 91.4 & 90.9 & 90.7 & 89.8 & 88.3 \\
\hline Crude protein & 6.2 & 22.6 & 14.5 & 14.4 & 5.2 \\
\hline Organic matter & 81.1 & 84.6 & 83.2 & 85.3 & 82.9 \\
\hline Neutral detergent fibre & 72.2 & 53.8 & 62.1 & 54.4 & 46.9 \\
\hline Acid detergent fibre & 43.5 & 36.6 & 47.8 & 42.5 & 28.7 \\
\hline Lignin & 7.1 & 5.5 & 7.1 & 5.8 & 3.8 \\
\hline Total ash & 11.4 & 6.5 & 8.5 & 6.4 & 5.1 \\
\hline
\end{tabular}

\section{Table 3 - Chemical composition of the experimental supplements}

\begin{tabular}{lcccc} 
Fraction (\%) & \multicolumn{4}{c}{ Supplement } \\
\cline { 2 - 5 } & SS-S & AA-S & FE-S & CP-S \\
\hline Dry matter & 89.9 & 90.4 & 90.8 & 89.7 \\
Crude protein & 19.1 & 22.3 & 21.7 & 15.9 \\
Organic matter & 85.2 & 84.1 & 82.4 & 84.1 \\
Neutral detergent fibre & 46.5 & 49.1 & 46.3 & 42.9 \\
Acid detergent fibre & 28.5 & 33.8 & 19.4 & 31.8 \\
Lignin & 4.1 & 4.4 & 5.3 & 3.9 \\
CP-S: cassava peels-based; SS-S: Samanea saman-based; AA-S: Acacia auriculiformis-based and FE-S: Ficus exasperata-based supplements
\end{tabular}

\section{Table 4 - Influence of supplements on voluntary intakes in West African Dwarf goat}

\begin{tabular}{|c|c|c|c|c|c|c|}
\hline \multirow{2}{*}{ Parameter (g/day) } & \multicolumn{4}{|c|}{ Treatments } & \multirow{2}{*}{ SEM } & \multirow{2}{*}{ P-value } \\
\hline & SS-S & AA-S & FE-S & CP-S & & \\
\hline Dry matter intake & 321.2 & 306.3 & 388.7 & 361.9 & 24.5 & 0.084 \\
\hline Organic matter & 297 & 282 & 353 & 334 & 22.5 & 0.109 \\
\hline Crude protein intake & $47.3^{a b}$ & $50.3^{a b}$ & $54.2^{a}$ & $45.1^{b}$ & 2.84 & 0.011 \\
\hline Neutral detergent fibre intake & 54.3 & 55.6 & 69.0 & 58.5 & 5.63 & 0.212 \\
\hline Acid detergent fibre intake & $36.9^{a}$ & $40.0^{a}$ & $41.4^{a}$ & $25.5^{b}$ & 3.59 & $<0.001$ \\
\hline Lignin intake & 27.9 & 31.4 & 30.2 & 21.0 & 3.63 & 0.119 \\
\hline
\end{tabular}


Table 5 - Digestibility of components of feed as influenced by supplementation

\begin{tabular}{|c|c|c|c|c|c|c|}
\hline \multirow{2}{*}{ Fraction (\%) } & \multicolumn{4}{|c|}{ Supplements } & \multirow{2}{*}{ SEM } & \multirow{2}{*}{$P$-value } \\
\hline & SS-S & AA-S & FE-S & CP-S & & \\
\hline Dry matter & $57.5^{a}$ & $56.8^{a}$ & $62.7^{a}$ & $47.7 \mathrm{~b}$ & 2.85 & $<0.012$ \\
\hline Organic matter & $52.4^{a}$ & $51.2^{\mathrm{ab}}$ & $58.6^{a}$ & $43.1^{b}$ & 3.10 & $<0.018$ \\
\hline Crude protein & $46.4^{a}$ & $47.2^{\mathrm{a}}$ & $46.5^{\mathrm{a}}$ & $38.7^{b}$ & 1.36 & $<0.001$ \\
\hline Neutral detergent fibre & $38.4^{a}$ & $40.2^{a}$ & $36.2^{a}$ & $30.7^{b}$ & 1.34 & $<0.001$ \\
\hline Acid detergent fibre & $33.4^{\mathrm{ab}}$ & $34.2^{a}$ & $29.5^{\mathrm{bc}}$ & $26.8^{c}$ & 1.37 & $<0.004$ \\
\hline
\end{tabular}

\section{Table 6 - Effect of supplementation on growth parameters in West African Dwarf goats}

\begin{tabular}{lcccccc}
\multirow{2}{*}{ Parameter } & \multicolumn{9}{c}{ Supplements } & \multicolumn{2}{c}{ SEM } & P-value \\
\cline { 2 - 5 } & SS-S & AA-S & FE-S & CP-S & & \\
\hline Initial weight $(\mathrm{kg})$ & 10.9 & 9.75 & 12.00 & 10.75 & 1.33 & 0.436 \\
Final weight $(\mathrm{kg})$ & 11.8 & 10.63 & 12.80 & 11.88 & 1.23 & 0.399 \\
Average daily gain $(\mathrm{g} / \mathrm{d})$ & 10.8 & 10.54 & 9.64 & 13.55 & 2.96 & 0.612 \\
Feed intake $(\mathrm{g})$ & 321.2 & 306.3 & 388.7 & 361.9 & 32.7 & 0.084 \\
Feed conversion ratio & 33.6 & 35.1 & 50.7 & 27.9 & 12.7 & 0.330 \\
a SEM: Standard error of mean; CP-S: cassava peels-based; SS-S: Samanea saman based; AA-S: Acacia auriculiformis-based and FE-S: Ficus \\
exasperata-based supplements
\end{tabular}

\section{Haematological and serum biochemical parameters in West African Dwarf sheep}

At the end of the study, dietary treatment did not affect all the haematological and serum biochemical indices measured except serum urea concentrations which was higher $(P<0.05)$ in goats fed SS-S than those fed AA-S, FE-S and CP-S (Table 7). Generally, the concentrations of most of the haemato-biochemical indices remained relatively stable and showed similar trends across dietary treatments during the period of study (Figures 1 and 2).

Table 7 - Haematological and serum biochemical parameters of West African Dwarf goat fed basal diet of Andropogon gayanus hay and supplements

\begin{tabular}{|c|c|c|c|c|c|c|c|}
\hline \multirow{2}{*}{ Parameters } & \multicolumn{4}{|c|}{ Treatments } & \multirow{2}{*}{ SEM } & \multirow{2}{*}{ P-value } & \multirow{2}{*}{$\begin{array}{c}\text { Reference } \\
\text { Range }^{1}\end{array}$} \\
\hline & SS-S & AA-S & FE-S & CP-S & & & \\
\hline \multicolumn{8}{|l|}{ Haematological Indices } \\
\hline Haemoglobin (g/dL) & 10.3 & 10.1 & 10.0 & 10.1 & 0.122 & 0.265 & $8-12$ \\
\hline PCV (\%) & 26.7 & 24.6 & 23.1 & 24.9 & 1.520 & 0.350 & $22-38$ \\
\hline $\mathrm{RBC}\left(\mathrm{x} 10^{12} \mathrm{~g} / \mathrm{L}\right)$ & 13.6 & 12.2 & 11.6 & 12.5 & 0.865 & 0.351 & $8-18$ \\
\hline $\operatorname{MCV}(f L)$ & 20.0 & 20.4 & 20.6 & 20.1 & 0.701 & 0.910 & $16-25$ \\
\hline $\mathrm{MCH}(\mathrm{pg})$ & 7.85 & 8.47 & 9.23 & 8.30 & 0.584 & 0.344 & $5-8$ \\
\hline $\mathrm{MCHC}(\mathrm{g} / \mathrm{dL})$ & 39.2 & 41.8 & 44.9 & 41.3 & 2.29 & 0.317 & $30-36$ \\
\hline WBC (x109/L) & 11.7 & 12.0 & 11.9 & 11.5 & 0.639 & 0.934 & $4-13$ \\
\hline Neutrophils (\%) & 50.8 & 48.6 & 45.4 & 44.0 & 2.45 & 0.189 & $30-48$ \\
\hline Lymphocyte (\%) & 46.9 & 50.1 & 51.6 & 53.0 & 2.64 & 0.360 & $50-70$ \\
\hline Eosinophils (\%) & 0.6 & 0.90 & 1.84 & 1.40 & 0.372 & 0.091 & $1-8$ \\
\hline Monocytes (\%) & 1.68 & 0.50 & 1.08 & 1.15 & 0.480 & 0.372 & $0-4$ \\
\hline Basophils (\%) & 0.00 & 0.00 & 0.00 & 0.00 & 0.000 & 0.000 & $0-1$ \\
\hline \multicolumn{8}{|l|}{ Serum Biochemical Indices } \\
\hline Glucose (mmol/L) & 1.20 & 1.30 & 1.50 & 1.49 & 0.130 & 0.261 & $2.78-4.16$ \\
\hline Total protein (g/L) & 60.3 & 55.7 & 55.6 & 59.4 & 0.260 & 0.145 & $60-70$ \\
\hline Albumin $(\mathrm{g} / \mathrm{L})$ & 29.8 & 29.3 & 28.7 & 28.1 & 0.090 & 0.519 & $27-39$ \\
\hline Globulin $(\mathrm{g} / \mathrm{L})$ & 30.6 & 26.4 & 26.9 & 31.3 & 0.220 & 0.291 & $27-41$ \\
\hline Total cholesterol ( $\mathrm{mmol} / \mathrm{L})$ & 3.43 & 3.37 & 4.00 & 4.28 & 0.461 & 0.097 & $2.07-3.37$ \\
\hline Urea $(\mathrm{mmol} / \mathrm{L})$ & 9.39 & 5.74 & 6.51 & 6.17 & 0.810 & 0.016 & $3.6-7.1$ \\
\hline Sodium (mmol/L) & 162 & 154 & 159 & 156 & 4.62 & 0.568 & $139-149$ \\
\hline Potassium(mmol/L) & 5.97 & 6.18 & 6.17 & 6.09 & 0.290 & 0.937 & $4.5-6.7$ \\
\hline
\end{tabular}


12

$\because$ SS-S $\rightarrow$ AA-S $\rightarrow$ FE-S $\rightarrow$ CP-S

11

7

Period of sampling (weeks)

Figure 1 - Changes in haemoglobin concentration in West African Dwarf sheep. CP-S: cassava peels-based; SS-S: Samanea saman based; AA-S: Acacia auriculiformis-based and FE-S: Ficus exasperata-based supplements.

8

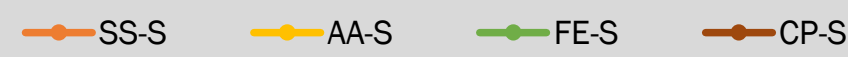

7

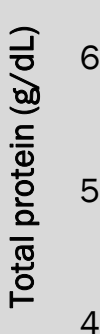

3

2

$$
1
$$

3

5

7

9

Period of sampling (weeks)

Figure 2 - Changes in total protein concentration in West African Dwarf sheep. CP-S: cassava peels-based; SS-S: Samanea saman based; AA-S: Acacia auriculiformis-based and FE-S: Ficus exasperata-based supplements.

\section{DISCUSSION}

The crude protein content of Samanea, Acacia and Ficus were higher than the mean values reported in the literature (Abdu et al., 2012; Bello et al., 2014; Delgado et al., 2014) probably due to varietal or environmental differences. Sheep fed FE-S had higher $(P<0.05)$ crude protein intake than those fed CP-S. This may be due to the higher crude protein content of FE-S resulting from the higher crude protein content of the Ficus leaf meal used (14.4\%) compared with values as low as $6.9 \%$ reported by Bello et al. (2012). The crude protein intake range of 45.1 to $54.2 \mathrm{~g} /$ day in this study was 
lower than the 59.6 to $67.0 \mathrm{~g} /$ day reported in an earlier study when the same supplements were fed to sheep (Adjorlolo et al., 2020).

The lower dry matter digestibility in sheep fed CP-S compared to the other treatments could be attributed to lower crude protein intake of this supplement. This suggests that for goats on grass hay nitrogen is the more limiting nutrient for the rumen microbes, compared with starch which is high in the cassava peels. Also, anti-nutritional factors such as cyanogenic glycosides in the cassava peels might have slowed down microbial action and thereby decreased dry matter digestibility. Anti-nutritional factors are known to interfere with normal digestion, metabolism and absorption of nutrients (Gilani et al., 2005). Crude protein and neutral detergent fibre digestibility also followed a similar tend to that of dry matter digestibility. The higher crude protein intake of goats fed SS-S, AA-S and FE-S based diets over CP-B diets could have enhanced the digestibility of crude protein and neutral detergent fibre in these supplements than the CP-B. The leaves of trees and shrubs are high in readily degradable nitrogen and some by-pass protein. Inclusion of such browses in ruminant diets will cause faster fermentation rate and substrate degradation hence increasing dry matter intake. The dry matter and crude protein digestibility obtained in the present study were comparable to the 54.7 to $68 \%$ and 44.0 to $59.0 \%$ respectively reported when Red Sokoto goats were fed elephant grass (Pennisetum purpereum) ensiled with varying proportions of cassava peels (Olorunnisomo, 2011).

The high organic matter digestibility for AA-S and FE-S diets than CP-S could be due to the provision of adequate nutrients to the rumen microbes with consequent improvement in organic matter intake whilst higher levels of cyanogenic glycosides in CP-S adversely affected rumen microbial activity resulting in lower organic matter digestibility. Also, the lower crude protein digestibility in goats fed CP-S may account for their lowest organic matter digestibility. The neutral detergent fibre digestibility was higher for SS-S, AA-S and FE-S than CP-B probably due to moderate concentrations of secondary metabolites in the Samanea, Acacia and Ficus leaf meals that might have had positive influence on rumen microbes in accordance with some reports that low or moderate concentrations of secondary metabolites positively impacts rumen fermentation (Salem et al., 2006; Jiménez-Peralta, 2011). The low crude protein level in CP-S could have inhibited rumen activity thus decreasing digestibility of neutral detergent fibre of goats fed that diet.

Similarity in weight gain for goats on CP-S to the other treatments, in spite of the differences in digestibility, may suggest similar metabolisable energy intake due to higher level of digestible starch in cassava peels. Daily weight gain in this study ranged from 9.64 to $13.6 \mathrm{~g} /$ day and feed conversion ratio ranged from 27.9 to 50.7 respectively. The average daily weight gains were comparable to the 10.4 to $18.7 \mathrm{~g} /$ day obtained when Philippine native goats were fed concentrates with different inclusion levels of Samanea Saman (Morais et al., 2018) but lower than in other studies when goats were fed grass- hay basal diets or grass and silage diets supplemented with browse tree leaves or leguminous tree foliage (Okoruwa, 2020; Okoruwa and Ikhimioya, 2020).

Blood indices serve as useful indicators of nutritional, physiologic, metabolic and health status of farm animals (Mirzadeh et al., 2010; Onasanya et al., 2015) and hence essential in evaluating the suitability of introduced feed resources. The non-significant but similar concentrations of haematological parameters measured in the present study suggest similar ability of the dietary treatments in enhancing the production of haemoglobin for efficient transportation of gases, normal synthesis of RBCs and production of enough WBCs to adequately defend the body against infections. The inclusion of the supplements did not adversely affect the health of the goats indicating that the quality of the supplementary diets was good to help sustain growth of goats during periods when animals rely on poor quality fodder. The levels of the haematological parameters measured were within the normal physiological ranges reported for goats (Merck Manual, 2012) and were also comparable to the values reported by Baiden et al. (2007), when West African Dwarf goats were fed varying levels of cassava pulp as a replacement for cassava peels.

The higher serum urea concentrations in goats fed SS-S than those fed AA-S, FE-S and CP-S might be due to the higher crude protein levels in the Samanea leaf meal than the Acacia and Ficus leaf meals and the cassava peel meal. Most concentrations of the serum biochemical indices determined were within the normal physiological range reported for goats (Merck Manual 2012) suggesting feeding the supplements did not have adverse effects on the physiology of the West African Dwarf goats. The concentration of the biochemical parameters measured compared favourably to the values obtained by Hassan et al. (2015) when they fed some forage shrubs made up of Acacia, Leucaena and Moringa to goats during the dry season.

\section{CONCLUSION}

Feeding the supplements influenced feed intake and growth performance to a similar extent and did not have any deleterious effect on the physiology and health of the goats. Therefore, all the four dietary supplements could be fed to confined goats on roughage diets especially in the dry season to overcome the adverse effects of seasonal fluctuation in feed quality on growth and health of goats.

\section{DECLARATIONS}

\section{Corresponding Author}

E-mail: fobese@ug.edu.gh; ORCiD: 0000-0001-6747-4786 


\section{Authors' Contribution}

LA conceived the study, participated in the design of the study, contributed to data analysis and the write up of the manuscript, EA participated in the data collection and contributed in data analysis and the write up of the manuscript, AM was in involved the design and data analysis of the study and contributed to the write up of the manuscript. FO participated in the design and coordination of the study, contributed to data analysis and the write up of the manuscript.

\section{Conflict of interests}

The authors have not declared any conflict of interests.

\section{Acknowledgements}

This project was made possible with financial support from the University of Ghana research fund.

\section{REFERENCES}

Abdu SB, Hasan MR, Adamu HY, Yashimi SM and Abdullahi MJ (2012). Intake, Nutrient Digestibility and Nitrogen Balance of Acacia auriculate, Gmelina arborea, Albizia lebbeck and Butryospermum parkii by Yankasa Bucks. Iranian Journal of Applied Animal Science 2(2): 121-125. Link I Google Scholar

Adjorlolo L, Nsoh M, Mensah-Bonsu A and Obese F (2020). Effect of pelleted browse-based feed with a basal diet of andropogon gayanus for sheep on intake, nutrient digestibility and some haematological and blood biochemical parameters. Online Journal of Animal and Feed Research 10 (3): 76-84. Google Scholar I DOI: https://dx.doi.org/10.36380/scil.2020.0jafr11

Adjorlolo LK, Adogla-Bessa T, Amaning-Kwarteng K and Ahunu BK (2014). Seasonal effect on rumen function in sheep on range in the Accra Plains of Ghana. Tropical Animal Health and Production, 46(7): 1223-1228. Google Scholar I DOI: https://doi.org/10.1007/s11250-014-0629-y

Adjorlolo LK, Timpong-Jones EC, Boadu S and Adogla-Bessa, T (2016). Potential contribution of neem (Azadirachta indica) leaves to dry season feeding of ruminants in West Africa. Livestock Research for Rural Development, 28: Article \#75. Google Scholar I http://www.Irrd.org/Irrd28/5/adjo28075.htm.

Annor SY, Djang-Fordjour KT and Gyamfi KA (2007). Is growth rate more important than survival and reproduction in sheep farming in Ghana. Journal of Science and Technology 27(3): 23-38. Google Scholar I DOI: 10.4314/just.v27i3.33056

AOAC (2004). Official Methods of Analysis. 18 ${ }^{\text {th }}$ Ed, Association of Official Analytical Chemists, Washington, D.C.

Baah J, Tuah AK, Addah W and Tait RM (2012). Small ruminant production characteristics in urban households in Ghana. Livestock Research for Rural Development. Volume 24, Article \#86. Google Scholar I DOI: http://www.Irrd.org/Irrd24/5/baah24086.htm

Baiden RY and Obese FY (2010). Performance of West African Dwarf sheep (the Djallonké) fed fattening diets containing agro-industrial by-products in Ghana. Ghanaian Journal of Animal Science 5:60-65. URI: http://197.255.68.203/handle/123456789/1590 Google Scholar

Baiden RY, Rhule SWA, Otsyina HR, Sottie ET and Ameleke G (2007). Performance of West African dwarf sheep and goats fed varying levels of cassava pulp as a replacement for cassava peels. Livestock Research for Rural Development, 19(3), Article \# 35. Google Scholar I DOI: http://www.Irrd.org/Irrd19/3/baid19035.htm

Bello MO, Abdul-Hammed M and Ogunbeku P (2014). Nutrient and Anti-nutrient Phytochemicals in Ficus exasperata Vahl Leaves. International Journal of Scientific and Engineering Research 5(1): 2177-2181. Google Scholar I https://www.ijser.org/onlineResearchPaperViewer.aspx?Nutrient-and-Anti-nutrient-Phytochemicals.pdf

Campbell TW (1995). Avian Hematology and Cytology. 2nd Edn., lowa State University Press, Ames, lowa, USA.

Delgado DC, Hera R, Cairo J and Orta Y (2014). Samanea saman, a multi-purpose tree with potentialities as alternative feed for animals of $\begin{array}{llllllll}\text { productive interest. } & \text { Cuban } & \text { Journal } & \text { Agricultural } & \text { Science } & 48 & \text { (3): } & 205-212 .\end{array}$ https://www.cjascience.com/index.php/CJAS/article/view/573 I Google Scholar

GenStat (2009). GenStat for Windows $12^{\text {th }}$ ed. VSN International Hemel Hempstead, UK. Google Scholar

Gilani GS, Cockell KA and Sepehr, E (2005). Effects of Antinutritional Factors on Protein Digestibility and amino Acid Availability in Foods. Journal of AOAC International, 88 (3): 967-987. Google Scholar

Gillet P, Boei L and Jacobs J (2009). Practical Note: Tropical Haematology. Antwerpen: Prince Leopold Institute of Tropical Medicine. Google Scholar

Hassan AA, Salma H, Hafsa A, Yacout MH, Khalel MS, Ibrahim MAR and Mocuta D (2015). Effect of feeding some forage shrubs on goats performance and rumen fermentation in dry season. Egyptian Journal of Sheep \& Goat Sciences, Proceedings Book of the 5th International Scientific Conference on Small Ruminant Production, Sharm El Sheikh-Egypt. pp 21-36. Google Scholar I https://www.researchgate.net/publication/292629242

Jiménez-Peralta FS, Salem AZM, Mejia-Hernández P, González-Ronquillo M, Albarrán-Portillo B, Rojo-Rubio R and Tinoco-Jaramillo JL (2011). Influence of individual and mixed extracts of two tree species on in vitro gas production kinetics of a high concentrate diet fed to growing lambs. Livestock Science, 136(2-3): 192-200. Google Scholar I DOI: https://doi.org/10.1016/j.livsci.2010.09.008

Konlan SP, Karikari PK and Ansah T (2012). Productive and blood indices of dwarf rams fed a mixture of rice straw and groundnut haulms alone or supplemented with concentrates containing different levels of shea nut cake. Pakistan Journal of Nutrition. 11(6): 566-571. Google Scholar I http://udsspace.uds.edu.gh/jspui/bitstream/123456789/559/1

Merck Manual (2012) Hematologic and serum biochemical reference ranges. Merck Veterinary manual. Merck Manuals.com. Link 1 , Link 2 I Google Scholar

Mirzadeh K, Tabatabaei S, Bojarpour M, and Mamoei M (2010). Comparative study of haematological parameters according to strain, age, sex, physiological status and season in Iranian cattle. Journal of Animal and Veterinary Advances. 9(16): 2123-2127. Google Scholar I DOI: 10.3923/javaa.2010.2123.2127

Morais MJ, Sevilla CC, Dizon JT, Manulat GL, Abes EEC and Angeles AA (2018). Growth Performance and Ruminal Metabolic Variables of Goats Fed Rain Tree (Samanea saman) Pods. Tropical Animal Science Journal 41(1): 22-28. Google Scholar I DOI: 10.5398/tasj.2018.41.1.22 
Okoruwa MI (2020). The effect of feeding leguminous tree foliages on performance of goats fed basal diets of grass and crop residues. Livestock Research for Rural Development. Volume 32, Article \#119. http://www.Irrd.org/Irrd32/7/odion32119.htmI

Okoruwa MI and Ikhimioya, I (2020). Influence of browse-tree leaves supplementation on digestibility, rumen fermentation and performance of goats fed mixed grass hay. Livestock Research for rural Development. Volume 32 , Article \#93. http://www.Irrd.org/Irrd32/6/odion32093.html

Olorunnisomo OA (2011). Elephant grass silage as dry season feed for goats: effect of cassava peel inclusion on performance and digestibility of the mixture. Tropical Animal Production Investigation. 14(1): 36-39. Google Scholar I Link

Onasanya GO, Oke FO, Sanni TM and Muhammad AI (2015). Parameters influencing haematological, serum and bio-chemical references in livestock animals under different management systems. Open Journal of Veterinary Medicine, 5: 181-189. Google Scholar I DOI: https://doi.org/10.4236/ojvm.2015.58025

Reece WO and Swenson MJ (2004). The composition and functions of blood. In: Reece, W.O. (ed). Duke's Physiology of Domestic Animals. 12th ed. Comstock Publishing Associates, Cornell University Press. Ithaca and London. p 26-51. Google Scholar

Salem AZM, Salem MZM, El-Adawya MM and Robinson PH (2006). Nutritive evaluations of some browse tree foliages during the dry season: Secondary compounds, feed intake and in vivo digestibility in sheep and goats. Animal Feed Science and Technology 127: 251-267. Google Scholar I https://doi.org/10.1016/j.anifeedsci.2005.09.005

Samour J (2006). Diagnostic value of hematology. Clinical Avian Medicine, 2: 587-610. Google Scholar

Van Soest PV, Robertson JB and Lewis BA (1991). Methods for dietary fibre, neutral detergent fibre, and nonstarch polysaccharides in relation to animal nutrition. Journal of Dairy Science, 74(10): 3583-3597. Google Scholar I DOI: https://doi.org/10.3168/jds.S0022-0302(91)78551-2 